Artikel Penelitian

\title{
Penerapan Metode Sonikasi terhadap Adsorpsi Fe(III) pada Zeolit Alam Teraktivasi
}

\author{
Zuri Rismiarti, Yuyun Yuniati, Rokiy Alfanaar \\ Program Studi Kimia, Fakultas Sains dan Teknologi, Universitas Ma Chung, Malang, Indonesia
}

\section{INFO ARTIKEL}

Sejarah artikel:

Revisi 26 September 2016

Diterima 8 November 2016

Tersedia online 12 November 2016

*Penulis korespondensi

Email: zuri.rismiarti@machung.ac.id

\section{ABSTRAK}

Iron(III) is widely used in the industries such as water treatment, sugarcane industry, concrete industry and coal mining. Industrial activity using $\mathrm{Fe}(\mathrm{III})$ has potential impact to environmental pollution problems due to some industries produced $\mathrm{Fe}$ waste that is one of the hazardous waste. Fe content excess might toxic effect to human health and the environment. Zeolite as adsorbent has been evaluated extensively for $\mathrm{Fe}$ and other heavy metals. Sonication method has been widely developed in polymer preparation. The method is more effective in operation time because the reaction rate increased and also more efficient on the usage of chemical reagents. However, these methods have not been applied in the adsorption process. The optimization of $\mathrm{pH}$, the ratio of $\mathrm{Fe}(\mathrm{III})$ with activated zeolite, the influence sonication time and temperature has been assessed for $\mathrm{Fe}(\mathrm{III})$ adsorption with an activated zeolite by sonication method. The formation of $\mathrm{Fe}(\mathrm{III})-\mathrm{SCN}$ complex assay was used for determination of $\mathrm{Fe}(\mathrm{III})$ adsorbed with using spectrophotometry method. The results showed a relatively short operation time (15 minutes), $\mathrm{pH} 4$, $\mathrm{T}=30^{\circ} \mathrm{C}$ with the ratio of $1: 50(\mathrm{~g} / \mathrm{mL})$ for the activated zeolite and $\mathrm{Fe}(\mathrm{III})$.

Keywords: zeolite, iron, adsorption, sonication

Besi(III) banyak digunakan dalam industri pengolahan air, pabrik tebu, industri beton dan pertambangan batu bara. Aktivitas industri yang menggunakan $\mathrm{Fe}(\mathrm{III})$ berpotensi menimbulkan masalah pencemaran lingkungan karena menghasilkan limbah Fe. Limbah ini berbahaya karena kelebihan kadar Fe dalam tubuh dapat berdampak buruk bagi kesehatan manusia dan lingkungan. Pemanfaatan zeolit sebagai adsorben Fe dan logam berat lain telah dikembangkan secara luas. Metode sonikasi telah banyak digunakan dalam pengolahan polimer karena lebih efektif dalam waktu operasi karena meningkatkan laju reaksi dan efisien dalam penggunaan bahan kimia. Akan tetapi, metode tersebut belum diterapkan dalam proses adsorpsi. Oleh sebab itu, penelitian ini fokus pada optimasi pH, rasio $\mathrm{Fe}$ (III) dengan zeolit teraktivasi, pengaruh waktu sonikasi dan suhu adsorpsi $\mathrm{Fe}(\mathrm{III})$ dengan zeolit teraktivasi menggunakan metode sonikasi. Penentuan adsorpsi Fe(III) tersebut dilakukan dengan spektrofotometri melalui pembentukan kompleks $\mathrm{Fe}(\mathrm{III})$-SCN. Hasil penelitian menunjukkan hasil optimum pada waktu yang relatif singkat ( 15 menit), pada $\mathrm{pH} 4, \mathrm{~T}=30^{\circ} \mathrm{C}$ dengan perbandingan $1: 50(\mathrm{~g} / \mathrm{mL})$ antara zeolit teraktivasi dan $\mathrm{Fe}(\mathrm{III})$.

Kata Kunci: zeolit, besi, adsorpsi, sonikasi 


\section{Pendahuluan}

Besi ( $\mathrm{Fe}$ ) di alam terdapat dalam dua bentuk, yaitu $\mathrm{Fe}(\mathrm{II})$ dan $\mathrm{Fe}(\mathrm{III})$. $\mathrm{Fe}(\mathrm{III})$ banyak digunakan dalam industri, misalnya senyawa $\mathrm{Fe}(\mathrm{III})$ sulfat dimanfaatkan sebagai koagulan dalam proses penjernihan air, bahan aditif semen pada industri beton, untuk menurunkan nilai COD (Chemical Oxygen Demand) limbah cair pabrik tebu yang mengandung pigmen cokelat gelap (melanoidin). Selain itu, Fe(III) digunakan sebagai oksidator dalam reduksi sulfur anorganik (pirit) batu bara (Aladin, Syarif, Wiyani, \& Rasyid, 2010).

Limbah Fe merupakan salah satu jenis limbah berbahaya. Kadar Fe dalam tubuh yang berlebihan dapat berdampak buruk bagi kesehatan manusia seperti gangguan pada susunan syaraf, insomnia, kaki dan otot wajah. Selain itu, limbah ini dapat menyebabkan pembengkakan pada hati dan mengurangi kemampuan tubuh untuk menyerap zat tembaga. Dosis $\mathrm{Fe}$ yang besar dalam tubuh dapat merusak dinding usus yang sehingga dapat menyebabkan kematian. Kadar Fe yang lebih dari $1 \mathrm{mg} / \mathrm{L}$ akan menyebabkan terjadinya iritasi pada mata dan kulit. Berdasarkan Keputusan Menteri Lingkungan Hidup Nomor 113 tahun 2003 tentang Baku Mutu Air Limbah bagi Usaha bahwa kandungan Fe total di dalam limbah cair dibatasi adalah $7 \mathrm{mg} / \mathrm{L}$ (ppm) (Kundari, Susanto, \& Prihatiningsih, 2010).

Industri yang menggunakan $\mathrm{Fe}(\mathrm{III})$ sebagai bahan baku yang berpotensi menghasilkan limbah sehingga dapat menimbulkan masalah pencemaran lingkungan. Oleh karena itu, perlu dilakukan tindakan penanganan limbah. Ada beberapa metode pengolahan limbah dan salah satunya adsorpsi berupa penyerapan suatu senyawa (adsorbat) dengan senyawa penyerap (adsorben).

Zeolit merupakan mineral alam dengan kandungan dominan $\mathrm{SiO}_{4}$ dan $\mathrm{AlO}_{4}$ serta memiliki kemampuan dalam penukar ion, adsorbsi, katalis dan dehidrasi serta penyaring atau pemisah (Wang, \& Peng, 2010). Pemanfaatan zeolit sebagai adsorben Fe telah dikembangkan secara luas (Oztas, Karabakan, \& Topal, 2008; Kundari et al., 2010; Aladin et al., 2010; Munandar, Krisdiyanto, Khamidinal, \& Artsanti, 2014). Kemampuan adsorpsinya dapat ditingkatkan melalui proses aktivasi. Proses aktivasi secara fisika dilakukan dengan pemanasan (kalsinasi) hingga $450^{\circ} \mathrm{C}$ untuk menguapkan air yang terparangkap dalam poripori kristal zeolit sehingga jumlah pori dan luas permukaan spesifiknya bertambah. Aktivasi secara kimia dilakukan dengan $\mathrm{HF} 1 \%, \mathrm{HCl} 6$ $\mathrm{M}$ dan $\mathrm{NH}_{4} \mathrm{Cl} 1 \mathrm{M}$ yang dapat menghasilkan lebih banyak pori dan kristal zeolit tertata lebih rapi (Buchori \& Budiyono, 2003; Lestari, 2010).

Teknik sonikasi merupakan penggunaan ultrasonik dengan frekuensi $20 \mathrm{KHz}-10 \mathrm{MHz}$, dan telah berhasil digunakan dalam proses preparasi zeolit sintesis. Teknik ini dinilai lebih efektif dan efisien dalam preparasi zeolit sintesis karena memerlukan waktu yang relatif lebih singkat dan tidak banyak bahan kimia yang terbuang. Dari segi keamanan, metode ini tergolong aman karena menggunakan frekuensi yang tidak terlalu tinggi. Selain itu, pada reaksi yang menggunakan bahan padat, ultrasonik dapat memecah padatan dari energi yang ditimbulkan akibat pecahnya kavitasi. Efeknya adalah memberikan komponen reaktan padat luas permukaan yang lebih besar untuk meningkatkan laju reaksi (Suslick, 1989; Purnama, Musthofa, Akhwan, \& Dewi, 2014).

Metode spektrofotometri dalam penentuan $\mathrm{Fe}$ (III) dapat menggunakan reagen tiosianat (SCN) sebagai agen pengompleks. Senyawa kompleks tersebut adalah $\left.\mathrm{Fe}(\mathrm{SCN})_{6}\right]^{]^{-}}$yang berwarna merah jingga dan stabil dalam asam $\left(\mathrm{HCl}, \mathrm{HNO}_{3}\right.$ dan $\left.\mathrm{H}_{2} \mathrm{SO}_{4}\right)$. Pengukuran kompleks tersebut pada panjang gelombang $480 \mathrm{~nm}$ (Rusmawan, Onggo, \& Mulyani, 2011).

Berdasarkan studi literatur tersebut, maka penelitian ini menggunakan teknik sonikasi terhadap proses adsorpsi Fe(III) dengan zeolit yang telah teraktivasi dan difokuskan pada optimasi waktu kontak, rasio $\mathrm{Fe}$ (III) dengan zeolit, dan pengaruh $\mathrm{pH}$, serta suhu. Penentuan $\mathrm{Fe}$ (III) yang teradsorpsi oleh zeolit dengan menggunakan metode spektrofotometri melalui pembentukan kompleks $\mathrm{Fe}(\mathrm{III})-\mathrm{SCN}$. Sonikasi diharapkan dapat menjadi metode alternatif yang efektif dan efisien dalam adsorpsi logam berat menggunakan zeolit teraktivasi. 


\section{Bahan dan metode}

\subsection{Bahan}

Bahan yang digunakan dalam penelitian ini adalah pro analisis (p.a.) antara lain zeolit alam dari Sumbermanjing Wetan Kabupaten Malang. Bahan lain yang digunakan adalah $\mathrm{FeCl}_{3}$ (EMerck), KSCN (E-Merck), $\mathrm{H}_{2} \mathrm{SO}_{4}$ (E-Merck), $\mathrm{HCl}$ (E-Merck), $\mathrm{HF}$ (E-Merck), $\mathrm{NH}_{4} \mathrm{Cl},($ E-Merck) dan akuades.

\subsection{Preparasi zeolit}

Zeolit ditumbuk halus menggunakan mortar kemudian diayak dengan ukuran 100 mesh. Selanjutnya dicuci dengan akuades dan dikeringkan dalam oven (Binder ED/BD) pada suhu $110^{\circ} \mathrm{C}$ selama 2 jam dan digunakan dalam percobaan selanjutnya

\subsection{Aktivasi zeolit}

Zeolit hasil preparasi sebesar $20 \mathrm{~g}$ direndam dalam $200 \mathrm{~mL}$ larutan HF $1 \%$ lalu diaduk dengan pengaduk elektrik selama 120 menit. Selanjutnya, campuran disaring dengan kertas saring Whatman No.40 dan dicuci dengan akuades hingga $\mathrm{pH}$ 7. Setelah itu, zeolit diaktivasi kembali dengan larutan $\mathrm{HCl} 6$ $\mathrm{M}$ kemudian $\mathrm{NH}_{4} \mathrm{Cl} 1 \mathrm{M}$ dengan masing-masing perlakuan sama dengan aktivasi menggunakan larutan HF 1\%. Kemudian, zeolit dipanaskan dalam tanur pada suhu $450^{\circ} \mathrm{C}$ selama 4 jam.

\subsection{Optimasi $\mathrm{pH}$}

Zeolit hasil aktivasi ditimbang sebesar $0,1 \mathrm{~g}$ lalu dimasukkan ke dalam tabung reaksi. Kemudian, ditambah $10 \mathrm{~mL}$ larutan Fe(III) 1000 ppm. Lalu, masing-masing larutan dikondisikan dengan $\mathrm{pH}$ media $2 ; 4 ; 7 ; 10$; dan 13 menggunakan larutan $\mathrm{HNO}_{3}$ dan $\mathrm{NaOH}$. Selanjutnya, dilakukan adsorpsi dengan menggunakan sonikator (Mosinix, USA) selama 15 menit pada frekuensi $32 \mathrm{kHz}$. Campuran disaring dengan kertas saring Whatman No.40. Kemudian, filtrat diambil dan dimasukkan ke dalam labu ukur $10 \mathrm{~mL}$ dan ditambah dengan

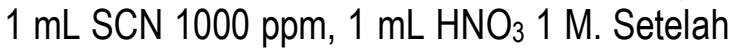
itu, diencerkan dengan akuades hingga tanda batas dan dikondiskan larutan hingga pH 2 .

Absorbansi $\mathrm{Fe}(\mathrm{III})$ diukur menggunakan spektrofotometer UV-Vis (Lab Tech) pada panjang gelombang $460 \mathrm{~nm}$. pH optimum ditunjukkan dari konsentrasi optimum $\mathrm{Fe}(\mathrm{III})$ yang teradsorpsi oleh zeolit dan hasil ini digunakan untuk perlakuan selanjutnya.

\subsection{Penentuan rasio Fe(III) dan zeolit}

Pengaruh rasio $\mathrm{Fe}(\mathrm{III})$ dan zeolit dilakukan dengan melakukan variasi volume $(\mathrm{mL}) \mathrm{Fe}(\mathrm{III})$ 100 ppm dan massa zeolit sebesar 0,1 g dengan rasio $1: 10 ; 1: 30 ; 1: 50 ; 1: 70 ; 1: 100$ $(\mathrm{g} / \mathrm{mL})$ berdasarkan hasil dari optimasi $\mathrm{pH}(2.4)$.

\subsection{Optimasi waktu sonikasi}

Optimasi waktu sonikasi dilakukan dengan melakukan variasi waktu dari $0,5,1,5,10,15$, dan 20 menit berdasarkan hasil dari optimasi $\mathrm{pH}$ (2.4) dan penentuan rasio $\mathrm{Fe}(\mathrm{III})$-zeolit (2.5).

\subsection{Pengaruh suhu}

Pengaruh suhu dilakukan dengan memvariasi suhu dari $25,30,40,50$, dan $60^{\circ} \mathrm{C}$ berdasarkan hasil optimasi $\mathrm{pH}(2.4)$, penentuan rasio $\mathrm{Fe}(\mathrm{III})$-zeolit (2.5) dan optimasi waktu sonikasi (2.6).

\section{Hasil dan pembahasan}

\subsection{Optimasi $\mathrm{pH}$}

Keberadaan spesi $\mathrm{Fe}(\mathrm{III})$ pada berbagai $\mathrm{pH}$ adalah $\mathrm{Fe}^{3+}$ pada $\mathrm{pH}<5$; $\mathrm{Fe}(\mathrm{OH})^{2+}$ pada $\mathrm{pH}<6$; $\mathrm{Fe}(\mathrm{OH})_{2}{ }^{+}$pada $\mathrm{pH}$ 2-9 sedangkan endapan $\mathrm{Fe}(\mathrm{OH})_{3}$ pada $\mathrm{pH}>8$ (Millero, 1998). Pengaruh $\mathrm{pH}$ terhadap adsorpsi Fe oleh zeolit ditunjukkan pada Gambar 1. Berdasarkan Gambar 1 menunjukkan semakin besar $\mathrm{pH}$ (semakin basa) maka logam $\mathrm{Fe}(\mathrm{III})$ yang teradsorpsi semakin turun. Pada $\mathrm{pH}$ yang sangat asam $(\mathrm{pH}$ 2) maka semakin banyak ion hidrogen $\left(\mathrm{H}^{+}\right)$ dalam larutan. Aktivitas $\mathrm{H}^{+}$yang terdapat di dalam larutan uji dapat berpotensi menjadi pengganggu untuk adsorpsi Fe(III) oleh zeolit. Semakin banyak jumlah $\mathrm{H}^{+}$dalam larutan sampel maka akan berkompetensi dengan $\mathrm{Fe}(\mathrm{III})$ untuk teradsorpsi dalam pori-pori zeolit. Semakin kecil ukuran ion dan semakin banyak jumlah $\mathrm{H}^{+}$maka cenderung teradsorpsi oleh permukaaan zeolit. Pada $\mathrm{pH}$ yang terlalu asam pH 2 daya serap $\mathrm{Fe}(\mathrm{III})$ oleh zeolit yang teraktivasi lebih rendah dibandingkan $\mathrm{pH} 4$. Oleh karena itu, $\mathrm{pH} 4$ diambil sebagai $\mathrm{pH}$ optimum dan digunakan untuk percobaan selanjutnya. 


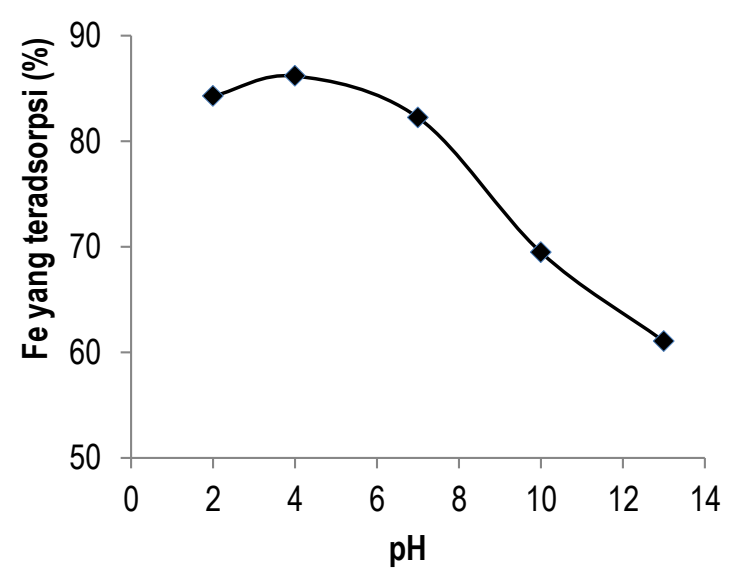

Gambar 1. Pengaruh $\mathrm{pH}$ terhadap $\mathrm{Fe}(\mathrm{III})$ yang teradsorpsi oleh zeolit teraktivasi.

Pada rentang $\mathrm{pH}$ 7-13 terjadi penurunan kemampuan adsorpsi. Kenaikan $\mathrm{pH}$ mengakibatkan bertambahnya ion $\mathrm{OH}^{-}$dalam larutan analit yang dapat menggangu mobilitas kation $\mathrm{Fe}(\mathrm{III})$ menuju permukaaan zeolit. Selain itu, pada $\mathrm{pH}$ netral $(\mathrm{pH} 7)$, spesi Fe(III) hanya berada dalam bentuk $\mathrm{Fe}(\mathrm{OH})_{2}{ }^{+}$yang dapat terikat oleh zeolit akibat gaya elektrostatis tarik menarik yang sangat kuat antara bagian negatif dari permukaan adsorben zeolit $\left(\mathrm{AlO}_{4}^{-}\right)$ sehingga proses adsorpsi masih dapat terjadi.

Penurunan kemampuan adsorpsi terjadi sangat signifikan pada $\mathrm{pH} 10$ dan 13. Hal ini dikarenakan pada $\mathrm{pH}$ sangat basa $(\mathrm{pH}>8)$ terbentuk $\mathrm{Fe}(\mathrm{OH})_{3}$ dalam larutan analit. Akibatnya, spesi ion $\mathrm{Fe}(\mathrm{III})$ dominan berada dalam bentuk endapan hidroksida sehingga menghambat proses adsorpsi. Pada kondisi ini efisiensi penghilangan ion $\mathrm{Fe}(\mathrm{III})$ dalam bentuk kation sangat tinggi. Hal ini berhubungan dengan kemampuan pertukaran ion dalam bentuk $\mathrm{Fe}^{3+}, \mathrm{Fe}(\mathrm{OH})^{2+}, \mathrm{Fe}(\mathrm{OH})_{2}{ }^{+}$sangat rendah.

\subsection{Penentuan rasio $\mathrm{Fe}(\mathrm{III}) 100$ ppm : zeolit aktivasi}

Penentuan rasio $\mathrm{Fe}$ (III) $100 \mathrm{ppm}$ dan zeolit disajikan pada Tabel 1. Tabel 1 menunjukkan perbandingan $\mathrm{Fe}(\mathrm{III}) 100$ ppm dengan zeolit teraktivasi pada 10:1 hingga $50: 1(\mathrm{~mL} / \mathrm{g})$ terjadi penurunan sisa hasil $\mathrm{Fe}(\mathrm{III})$ yang telah teradsorpsi oleh zeolit sehingga terjadi peningkatan kemampuan adsorpsi. Adsorpsi ion $\mathrm{Fe}(\mathrm{III})$ merupakan akibat dari gaya elektrostatis tarik menarik yang sangat kuat antara bagian negatif dari permukaan adsorben zeolit dengan bagian positif dari kation $\mathrm{Fe}(\mathrm{III})$.
Semakin besar jumlah ion $\mathrm{Fe}(\mathrm{III})$ dalam larutan analit, maka semakin banyak ion $\mathrm{Fe}(\mathrm{III})$ yang berinteraksi dengan situs zeolit $\left(\mathrm{AlO}_{4}^{-}\right)$. Oleh sebab itu, dengan meningkatnya volume $(\mathrm{mL})$ dalam larutan analit maka semakin banyak jumlah ion $\mathrm{Fe}^{3+}, \mathrm{Fe}(\mathrm{OH})^{2+}, \mathrm{Fe}(\mathrm{OH})_{2}{ }^{+}$. Akibatnya, ion-ion tersebut dapat mudah terikat dalam zeolit yang mempunyai situs $\mathrm{AlO}_{4}^{-}$ sehingga terjadi peningkatan kemampuan adsorpsi. Rasio Fe(III) 100 ppm dengan zeolit teraktivasi 50:1 (mL/g) merupakan komposisi optimum dan digunakan sebagai acuan pada percoban selanjutnya.

\section{Tabel 1.}

Penentuan rasio $\mathrm{Fe}(\mathrm{III}) 100$ ppm : zeolit aktivasi

\begin{tabular}{ccc}
\hline $\begin{array}{c}\text { Rasio Fe(III) 100 } \\
\text { ppm : zeolit } \\
\text { aktivasi (mL/g) }\end{array}$ & $\begin{array}{c}\text { Fe } \\
\text { setimbang } \\
\text { (ppm) }\end{array}$ & $\begin{array}{c}\text { Fe yang } \\
\text { teradsorpsi } \\
\text { zeolit (\%) }\end{array}$ \\
\hline 10 & 19,84 & 80,16 \\
30 & 14,13 & 85,87 \\
50 & 13,83 & 86,17 \\
70 & 20,80 & 79,20 \\
100 & 33,56 & 66,44 \\
\hline
\end{tabular}

Pada rasio 70:1 hingga 100:1 antara Fe(III) 100 ppm dengan zeolit teraktivasi terjadi penurunan kemampuan adsorpsi Fe(III) (Tabel 1). Hal ini dikarenakan jumlah zeolit sebagai situs aktif adsorben sangat sedikit (situs $\mathrm{AlO}_{4}^{-}$) dibandingkan ion $\mathrm{Fe}^{3+}, \mathrm{Fe}(\mathrm{OH})^{2+}, \mathrm{Fe}(\mathrm{OH})_{2}{ }^{+}$ yang sangat banyak dalam larutan analit. Jumlah maksimum ion $\mathrm{Fe}(\mathrm{III})$ yang ditranspor dapat ditentukan oleh jumlah muatan $\left(\mathrm{AlO}_{4}{ }^{-}\right)$ dalam zeolit. Dengan demikian, semakin banyak komponen zeolit maka semakin banyak situs $\mathrm{AlO}_{4}^{-}$yang tersedia untuk mengikat ion $\mathrm{Fe}(\mathrm{III})$ sehingga dapat terserap ke dalam zeolit.

\subsection{Optimasi waktu sonikasi}

Penentuan waktu sonikasi disajikan pada Gambar 2 yang menunjukkan bahwa semakin lama waktu adsorpsi maka semakin banyak $\mathrm{Fe}(\mathrm{III})$ yang teradsorpsi oleh zeolit hingga menit ke-15 dan mengalami penurunan pada menit ke-20. Pada menit ke-0,5 hingga menit ke-15 mengindikasikan kemampuan adsorpsi Fe(III) oleh zeolit semakin meningkat sebanding dengan bertambahnya waktu sonikasi. Waktu adsorpsi yang terlalu singkat dapat diduga 
bahwa ion $\mathrm{Fe}(\mathrm{III})$ yang masuk untuk berasosiasi dengan situs $\mathrm{AlO}_{4}^{-}$pada zeolit masih sedikit sehingga mempengaruhi kemampuan adsorpsi dan pertukaran kationnya. Waktu kesetimbangan pada penelitian ini adalah 15 menit yang ditunjukkan dari nilai $\mathrm{Fe}(\mathrm{III})$ yang terserap sebesar $86,17 \%$.

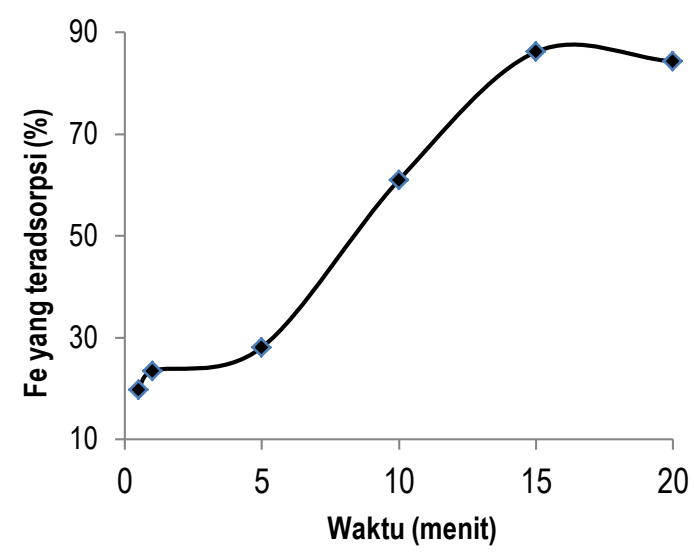

Gambar 2. Optimasi waktu kontak adsorpsi

Medan ultrasonik akan menghasilkan efek kimia dan fisika yang diakibatkan oleh meledaknya gelembung kavitasi mikro yang disebabkan getaran ultrasonik sehingga efek tersebut berdampak pada terjadinya proses sonokimia. Proses ini berdampak pada kinetika kimia. Ultrasonik dapat meningkatkan kereaktifan kimia pada suatu sistem yang secara efektif bertindak sebagai katalis untuk lebih mereaktifkan atom-atom dan molekul dalam sistem. Oleh sebab itu, terjadi peningkatan $\mathrm{Fe}$ (III) yang teradsorpsi dengan bertambahnya waktu sonikasi.

Pada menit ke-20, kemampuan adsorpsi sudah mengalami penurunan. Hal ini dikarenakan dengan bertambahnya waktu adsorpsi, laju transfer massa semakin kecil dan akhirnya konstan (Emelda, Putri, \& Ginting, 2013). Fenomena tersebut menjelaskan bahwa kemampuan zeolit dalam menyerap ion $\mathrm{Fe}^{3+}$, $\mathrm{Fe}(\mathrm{OH})^{2+}, \mathrm{Fe}(\mathrm{OH})_{2}{ }^{+}$semakin menurun hingga pada waktu tertentu zeolit tidak dapat menyerap ion tersebut yang ditunjukkan dari penurunan persentase $\mathrm{Fe}$ yang terserap oleh zeolit teraktivasi. Hal ini disebabkan oleh sisi aktif zeolit teraktivasi sudah terisi oleh ion $\mathrm{Fe}(\mathrm{III})$ hingga kemampuan zeolit sebagai adsorben telah jenuh dan tidak mampu lagi menyerap $\mathrm{Fe}(\mathrm{III})$.

\subsection{Pengaruh suhu}

Pengaruh suhu adsorpsi ditunjukkan pada Tabel 2. Berdasarkan Tabel 2, kenaikan suhu akan menurunkan kemampuan adsorpsi ion $\mathrm{Fe}$ (III) terhadap zeolit. Proses aktivasi secara fisika dengan kalsinasi pada suhu $450^{\circ} \mathrm{C}$ dan aktivasi secara kimia dengan penambahan $\mathrm{HF}$ $1 \%, \quad \mathrm{HCl} \quad 6 \quad \mathrm{M}$ dan $\mathrm{NH}_{4} \mathrm{Cl} 1 \mathrm{M}$ dapat menghasilkan lebih banyak pori dan kristal zeolit tertata lebih rapi (Buchori \& Budiyono, 2003; Lestari, 2010). Akibatnya, ketika pemanasan hingga $60^{\circ} \mathrm{C}$, zeolit tidak akan mengalami degradasi termal. Hal ini karena zeolit memiliki ketahanan terhadap suhu atau memiliki stabilitas termal yang tinggi.

Tabel 2.

Optimasi suhu adsorpsi

\begin{tabular}{ccc}
\hline $\begin{array}{c}\text { Suhu } \\
\left({ }^{\circ} \mathrm{C}\right)\end{array}$ & $\begin{array}{c}\text { Fe setimbang } \\
(\mathbf{p p m})\end{array}$ & $\begin{array}{c}\text { Fe yang teradsorpsi } \\
\text { zeolit }(\%)\end{array}$ \\
\hline 25 & 13,83 & 86,17 \\
30 & 13,78 & 86,22 \\
40 & 14,08 & 85,92 \\
50 & 15,90 & 84,10 \\
60 & 17,86 & 82,14 \\
\hline
\end{tabular}

Pada suhu $25-30^{\circ} \mathrm{C}$ terlihat bahwa terjadi peningkatan kemampuan adsorpsi $\mathrm{Fe}$ (III) yang tidak terlalu signifikan atau bahkan hampir konstan. Hal ini dapat dijelaskan bahwa kenaikan suhu dapat memutuskan interaksi antara pelarut-terlarut yaitu ikatan van der Waals, ikatan hidrogen dan interaksi dipol sehingga difusi ion-ion $\mathrm{Fe}(\mathrm{III})$ dalam larutan analit lebih cepat (Ali et al., 2014). Dengan peningkatan suhu larutan analit maka mobilitas ion-ion $\mathrm{Fe}(\mathrm{III})$ juga semakin meningkat karena ion-ion dalam larutan menyerap energi panas. Oleh sebab itu, suhu adsorpsi optimum adalah pada $25-30^{\circ} \mathrm{C}$.

Pada suhu $40-60^{\circ} \mathrm{C}$ terjadi penurunan daya serap adsorpsi $\mathrm{Fe}(\mathrm{III})$ oleh zeolit. Hal ini disebabkan oleh sifat adsorpsi eksotermis (penurunan $\Delta \mathrm{G}$ dan $\Delta \mathrm{H}$ ) oleh ion $\mathrm{Fe}(\mathrm{III}) \mathrm{ke}$ dalam zeolit sehingga jumlah ion Fe(III) yang terserap pada kondisi setimbang semakin sedikit dengan meningkatnya suhu (Emelda et al., 2013). Selain itu, dorongan penyerapan antara situs aktif zeolit dengan ion logam Fe(III) semakin melemah akibat adsorpsi berlangsung secara eksotermis. Selain itu, pada suhu tinggi 
juga dimungkinkan terjadi desorpsi, yaitu pelepasan kembali ion $\mathrm{Fe}(\mathrm{III})$ yang sudah terikat pada situs aktif zeolit $\left(\mathrm{AlO}_{4}^{-}\right)$. Akibatnya, kemampuan adsorpsi $\mathrm{Fe}(\mathrm{III})$ oleh zeolit mengalami penurunan.

Faktor lain yang mempengaruhi adalah terbentuknya kavitasi penguapan yang merupakan peleburan antara gelembung akustik dengan gelembung dari uap sehingga terjadi penurunan efek efisiensi ultrasonik (Ali, 2014). Disamping itu, peningkatan suhu akan meningkatkan molekul bebas air. Akibatnya, proses mobilitas dan transpor ion $\mathrm{Fe}(\mathrm{III})$ menuju adsorben zeolit terhambat oleh adanya molekul air bebas tersebut.

\section{Kesimpulan}

Sonikasi dapat menjadi metode alternatif dalam proses adsorpsi $\mathrm{Fe}$ (III) dengan zeolit yang telah teraktivasi dengan waktu yang relatif singkat ( 15 menit), pada $\mathrm{pH} 4, \mathrm{~T}=30^{\circ} \mathrm{C}$ dengan perbandingan 1:50 ( $/ \mathrm{gL})$ antara zeolit teraktivasi dan $\mathrm{Fe}(\mathrm{III})$. Teknik ini diharapkan juga dapat diaplikasikan pada adsorpsi logam berat lain.

\section{Ucapan terima kasih}

Terima kasih ditujukan kepada Universitas Ma Chung atas dukungan dana penelitian melalui program Penelitian Dosen Pemula.

\section{Daftar pustaka}

Aladin, A., Syarif, T., Wiyani, L., \& Rasyid, R. (2010). Pengolahan serbuk limbah besi menjadi besi(III): tinjauan kinetika model quasi steady state. Reaktor, 13(2), 74-80.

Ali, F., Reinert, L., Leveque, J.M., Duclaux, L., Muller, F., Saeed, S., \& Shah, S.S. (2014). Effect of sonication conditions: solvent, time, temperature and reactor type on the preparation of micron sized vermiculite particles. Ultrasonics Sonochemistry, 21(3), 1002-1009.

Buchori, L., \& Budiyono. (2003). Aktivasi zeolit dengan menggunakan perlakuan asam dan kalsinasi. Seminar Nasional Teknik Kimia Indonesia. Yogyakarta.
Emelda, L., Putri, S.M., \& Ginting, S. (2013). Pemanfaatan zeolit alam teraktivasi untuk adsorpsi logam krom $\left(\mathrm{Cr}^{3+}\right)$. Jurnal Rekayasa Kimia dan Lingkungan, 9(4), 166-172.

Kundari, N.A., Susanto, A., \& Prihatiningsih, M.C. (2010). Adsorpsi Fe dan Mn dalam limbah cair dengan zeolit alam. Seminar Nasional VI SDM Teknologi Nuklir, (pp. 705-710). Yogyakarta.

Lestari, D. Y. (2010). Kajian modifikasi dan karakterisasi zeolit alam dari berbagai negara. Prosiding Seminar Nasional Kimia dan Pendidikan Kimia. Yogyakarta: Universitas Negeri Yogyakarta.

Millero, F. J. (1998). Solubility of $\mathrm{Fe}(\mathrm{III})$ in seawater. Earth and Planetary Science Letters, 154(1-4), 323-329.

Munandar, A., Krisdiyanto, D., Khamidinal, \& Artsanti, P. (2014). Adsorpsi logam Pb dan Fe dengan zeolit alam teraktivasi asam sulfat. Seminar Nasional dan Pendidikan Kimia VI (pp. 138-146). Surakarta: Universitas Sebelas Maret.

Oztas, N.A., Karabakan, A., \& Topal, O. (2008). Removal of $\mathrm{Fe}(\mathrm{III})$ ion from aqueous solution by adsorption raw and treated clinoptilolite samples. Microporous and Mesoporous Materials, 111(1-3), 200205.

Purnama, H., Musthofa, M., Akhwan, A.H., \& Dewi, I.K. (2014). Effect of ultrasound on zeolite preparation from rice husk ash. Proceedings of the $3^{\text {rd }}$ Applied Science for Technology Innovation, ASTECHNOVA, (pp. 24-30). Yogyakarta.

Rusmawan, C.A., Onggo, D., \& Mulyani, I. (2011). Analisis kolorimetri kadar besi(III) dalam sampel air sumur dengan metoda pencitraan digital. Prosiding Simposium Nasional Inovasi Pembelajaran dan Sains. Bandung.

Suslick, K. S. (1989). The chemical effects of ultrasound. Encyclopedia Britannica.

Wang, S., \& Peng, Y. (2010). Natural zeolites as effective adsorbents in water and wastewater treatment. Chemical Engineering Journal, 156(1), 11-24. 